\title{
Metachronous colorectal liver metastases has better prognosis - is it true?
}

\author{
Claudemiro QUIREZE JUNIOR' ${ }^{1}$, Andressa Machado Santana BRASIL², Lúcio Kenny MORAIS ${ }^{1}$, \\ Edmond Raymond Le CAMPION ${ }^{1}$, Eliseu José Fleury TAVEIRA ${ }^{3}$ and Matheus Castrillon RASSI ${ }^{1}$
}

\begin{abstract}
Background - Liver metastases from colorectal cancer are an important public health problem due to the increasing incidence of colorectal cancer worldwide. Synchronous colorectal liver metastasis has been associated with worse survival, but this prognosis is controversial. Objective - The objective of this study was to evaluate the recurrence-free survival and overall survival between groups of patients with metachronous and synchronous colorectal hepatic metastasis. Methods - This was a retrospective analysis of medical records of patients with colorectal liver metastases seen from 2013 to 2016, divided into a metachronous and a synchronous group. The Cox regression model and the Kaplan-Meier method with log-rank test were used to compare survival between groups. Results - The mean recurrence-free survival was 9.75 months and $50 \%$ at 1 year in the metachronous group and 19.73 months and $63.3 \%$ at 1 year in the synchronous group. The mean overall survival was 20.00 months and $6.2 \%$ at 3 years in the metachronous group and 30.39 months and $31.6 \%$ at 3 years in the synchronous group. Patients with metachronous hepatic metastasis presented worse overall survival in multivariate analysis. The use of biological drugs combined with chemotherapy was related to the best overall survival prognosis. Conclusion - Metachronous colorectal hepatic metastasis was associated with a worse prognosis for overall survival. There was no difference in recurrence-free survival between metachronous and synchronous metastases.
\end{abstract}

HEADINGS - Colorectal neoplasms. Neoplastic metastasis. Liver. Prognosis. Survival.

\section{INTRODUCTION}

Hepatic metastases from colorectal cancer are an important public health problem due to the increasing incidence of colorectal cancer worldwide $^{(1)}$. Hepatic metastases from colorectal cancer may be present in $15 \%$ to $20 \%$ of cases at diagnosis and in up to $60 \%$ of cases during the life of these patients ${ }^{(2)}$. The liver is the only site of metastasis in $20 \%$ to $50 \%$ of cases $^{(3)}$. Hepatic metastases may be present from the diagnosis of primary colorectal neoplasia or even be diagnosed before it. In this case, they are called synchronous metastases when they occur in the first 6 months after diagnosis of primary colorectal neoplasia ${ }^{(4)}$. Metastases diagnosed after 6 months are called metachronous ${ }^{(4)}$. However, this definition is heterogeneous, since other time intervals are adopted between the diagnosis of the primary tumour and of the liver metastasis, ranging from 0 to 12 months $^{(5)}$.

Numerous therapeutic innovations have been developed in the last decade with the intention of improving the prognosis and increasing the survival of patients with hepatic metastasis ${ }^{(6-8)}$. Such advances in therapy were able to contribute to this goal, with new surgical techniques such as associating liver partition and portal vein ligation for staged hepatectomy (ALPPS), staged resections, selective ligation of the portal vein branch, use of intraoperative ultrasound, and modern chemotherapy regimens associated with biological agents ${ }^{(9-12)}$.
Synchronous colorectal liver metastasis is classically associated with worse prognosis, being a component of several prognostic scores $^{(13-17)}$. However, there are discordant studies showing that the survival of synchronous liver metastasis does not differ from metachronous metastasis ${ }^{(18-20)}$. In view of the divergent results, there is a need for a new approach on the subject, given the rapid evolution of systemic and surgical treatments for colorectal liver metastases.

The objective of this study was to evaluate the recurrence-free survival and overall survival between groups of patients with metachronous and synchronous colorectal hepatic metastasis.

\section{METHODS}

A retrospective analysis of the data of patients with colorectal liver metastases treated at the Clinical Hospital of the Federal University of Goias from 2013 to 2016 was performed. Patients were divided into two groups: metachronous group (time between diagnosis of primary tumour and liver metastasis greater than 6 months) and synchronous group (time less than or equal to 6 months). Patients with multiple primary neoplasms or unavailable data were excluded from the study.

Clinical, anatomical, and surgical characteristics and their distributions between the two groups were evaluated. The variables studied were age, gender, location of primary tumour, extrahepatic disease, carcinoembryonic antigen (CEA), KRAS/NRAS gene ex-

Declared conflict of interest of all authors: none

Disclosure of funding: no funding received

${ }^{1}$ Universidade Federal de Goiás, Faculdade de Medicina, Hospital das Clínicas, Departamento de Cirurgia, Goiânia, GO, Brasil. ${ }^{2}$ Universidade Federal de Goiás, Programa de Pós-Graduação em Ciências da Saúde, Goiânia, GO, Brasil. ${ }^{3}$ Universidade Federal de Goiás, Hospital das Clínicas, Goiânia, GO, Brasil.

Corresponding author: Claudemiro Quireze Junior. Orcid: 0000-0002-5569-5052 E-mail: cquirezejr@gmail.com 
pression, degree of cell differentiation, number of liver metastases, number of hepatic segments affected, distribution of metastases, surgical treatment performed, chemotherapy scheme, biological drugs, use of intraoperative ultrasound, transfusion of blood products, surgical complications, size of the surgical margins of resected liver metastasis, and recurrence site.

Recurrence-free survival and overall survival were compared between the metachronous and synchronous groups. The followup period was at least 12 months in both groups, with periodic computer tomography (CT) and seric carcinoembryonic antigen (CEA) protocol. PET-SCAN was also used at the multidisciplinary team's discretion. The effect of all variables studied on survival in the total study population in univariate and multivariate analyses was also studied.

The chi-squared test was used to compare the clinical, anatomical, and surgical variables between the synchronous and metachronous groups. Survival curves were obtained using the Kaplan-Meier method, and the log-rank test was used to compare the groups. The Cox regression model was used in multivariate analysis to identify the variables associated with recurrence-free survival and overall survival; it included variables that presented $P$-values $<0.1$ in the univariate analysis. The risk prediction was exposed through the $P$-value, hazard ratio (HR), and 95\% confidence interval (95\% $\mathrm{CI})$. The differences were considered statistically significant when $P<0$.05. Statistical analysis was performed using SPSS ${ }^{\circledR}$ for Windows ${ }^{\circledR}$, version 16.0 .

This study was approved by the Research Ethics Committee of the Clinical Hospital of Federal University of Goias (protocol number $1,595,740$ ).

\section{Availability of data and materials}

The datasets used and/or analysed during the current study are available from the corresponding author on reasonable request.

\section{RESULTS}

A total of 59 records were analysed, of which 54 were included in the study. One patient had no diagnosis of liver metastasis confirmed on follow-up imaging and was excluded; three patients were excluded due to the absence of histological evidence of colorectal primary neoplasia; and one patient was excluded because of two primary neoplasms of different origins. Thus, the metachronous group consisted of 16 patients, and the synchronous group contained 38 patients.

\section{Clinical aspects}

The mean age of the patients was 58.6 years in the metachronous group and 57.1 years in the synchronous group. There was a predominance of males in both groups.

The median CEA value was $34.53 \mathrm{ng} / \mathrm{mL}$ in the metachronous group and $12.45 \mathrm{ng} / \mathrm{mL}$ in the synchronous group. The genetic study of the KRAS/NRAS family showed the prevalence of the wild type in both groups.

A moderate degree of cell differentiation predominated in both groups.

The use of biological therapy associated with the chemotherapy regimen (5-fluorouracil and/or capecitabine associated with oxaliplatin and/or irinotecan) was more frequent in the synchronous group, but without statistical significance. The biological agents used in the study were bevacizumab, cetuximab, and panitumumab.
Among the patients operated on for hepatic metastasis, the patients in the synchronous group underwent more preoperative chemotherapy treatments than the metachronous group, but without statistical significance. The comparison of clinical features between the groups is displayed in TABLE 1 .

TABLE 1. Clinical features of patients in synchronous and metachronous groups.

\begin{tabular}{|c|c|c|c|c|c|}
\hline & \multicolumn{2}{|c|}{ Synchronous } & \multicolumn{2}{|c|}{ Metachronous } & \multirow{2}{*}{$P$-value } \\
\hline & $\mathrm{n}$ & $\%$ & $\mathrm{n}$ & $\%$ & \\
\hline \multicolumn{6}{|l|}{ Age } \\
\hline$\leq 60$ years & 19 & 50.0 & 9 & 56.3 & \multirow{2}{*}{0.675} \\
\hline$>60$ years & 19 & 50.0 & 7 & 43.7 & \\
\hline \multicolumn{6}{|l|}{ Gender } \\
\hline Male & 20 & 52.6 & 10 & 62.5 & \multirow{2}{*}{0.505} \\
\hline Female & 18 & 47.4 & 6 & 37.5 & \\
\hline \multicolumn{6}{|l|}{ CEA } \\
\hline$<50 \mathrm{ng} / \mathrm{mL}$ & 26 & 68.4 & 10 & 66.7 & \multirow{2}{*}{0.902} \\
\hline$\geq 50 \mathrm{ng} / \mathrm{mL}$ & 12 & 31.6 & 5 & 33.3 & \\
\hline \multicolumn{6}{|l|}{ KRas/NRas } \\
\hline Mutated & 12 & 46.2 & 3 & 33.3 & \multirow{2}{*}{0.503} \\
\hline Wild-type & 14 & 53.8 & 6 & 66.7 & \\
\hline \multicolumn{6}{|c|}{ Differentiation grade } \\
\hline Well & 3 & 9.7 & 1 & 6.7 & \multirow{3}{*}{0.606} \\
\hline Moderate & 23 & 74.2 & 13 & 86.7 & \\
\hline Poor & 5 & 16.1 & 1 & 6.7 & \\
\hline \multicolumn{6}{|c|}{ Biological drugs } \\
\hline No & 16 & 44.4 & 11 & 68.8 & \multirow{2}{*}{0.105} \\
\hline Yes & 20 & 55.6 & 5 & 31.3 & \\
\hline \multicolumn{6}{|c|}{ Preoperative chemotherapy } \\
\hline Yes & 10 & 55.6 & 2 & 40.0 & \multirow{2}{*}{0.538} \\
\hline No & 8 & 44.4 & 3 & 60.0 & \\
\hline
\end{tabular}

\section{Anatomical aspects}

Primary colorectal neoplasia occurred more frequently in the left colon in both groups. Metastatic disease occurred exclusively in the liver at higher frequency in both groups.

The metachronous group had up to three hepatic lesions in most of the cases, unlike the synchronous group, which presented more lesions, but without statistical significance. Both groups showed a predominance of up to four hepatic segments affected by metastases.

Hepatic metastatic disease was predominantly unilobar in the metachronous group, unlike the synchronous group, in which there was a predominance of bilobar metastasis, but without statistical significance. The comparison of the anatomical characteristics between the groups is displayed in TABLE 2. 
TABLE 2. Anatomical characteristics of patients with synchronous and metachronous colorectal liver metastases.

\begin{tabular}{cccccc}
\hline & \multicolumn{2}{c}{ Synchronous } & \multicolumn{2}{l}{ Metachronous } & P-value \\
\cline { 2 - 5 } & $\mathrm{n}$ & $\%$ & $\mathrm{n}$ & $\%$ & \\
\hline
\end{tabular}

Location of primary tumour

$\begin{array}{llllll}\text { Rectum } & 12 & 31.6 & 5 & 31.3 & \\ \text { Colon } & 26 & 68.4 & 11 & 68.8 & \end{array}$

Colon affected

$\begin{array}{lccccc}\text { Right } & 6 & 23.1 & 3 & 27.3 & \\ \text { Left } & 20 & 76.9 & 8 & 72.7 & 0.786\end{array}$

Extrahepatic disease

$\begin{array}{lllll}\text { No } & 22 & 57.9 & 9 & 56.3 \\ \text { Yes } & 16 & 42.1 & 7 & 43.8\end{array}$

0.911

Number of liver metastases

$\begin{array}{lllll}\leq 3 & 18 & 47.4 & 9 & 56.3 \\ >3 & 20 & 52.6 & 7 & 43.8\end{array}$

0.551

Number of hepatic segments affected

$$
\begin{array}{lllll}
\leq 4 & 21 & 55.3 & 10 & 66.7 \\
>4 & 17 & 44.7 & 5 & 33.3
\end{array}
$$

0.448

Distribution of metastases

$\begin{array}{lllll}\text { Unilobar } & 14 & 36.8 & 9 & 56.3 \\ \text { Bilobar } & 24 & 63.2 & 7 & 43.8\end{array}$

0.188

Hepatic lobe affected

\begin{tabular}{lccccc} 
Right & 10 & 71.4 & 4 & 50.0 & \\
Left & 4 & 28.6 & 4 & 50.0 & 0.315 \\
\hline
\end{tabular}

Chi-squared test.

\section{Surgical aspects}

Approximately one-third of the patients in the metachronous group and almost half of the patients in the synchronous group underwent surgical treatment of hepatic metastasis. The most performed surgeries were non-anatomical surgeries in both groups.

Intraoperative hepatic ultrasound was used as an auxiliary diagnostic resource in the majority of cases, and in most cases, there was no need for intraoperative blood transfusion in both groups.

Postoperative surgical complications were more frequent in the metachronous group, but without statistical significance.

Among the liver resections, excluding laparotomies with findings of unresectable disease, $\mathrm{R} 0$ surgeries were performed in most surgeries in both groups. Surgical margins were disease free and $\geq 1 \mathrm{~cm}$ in both groups.

In the metachronous group, extrahepatic pulmonary recurrence was predominant, whereas in the synchronous group, hepatic recurrence was more frequent, but without statistical significance. The comparison of surgical features between the groups is displayed in TABLE 3.
TABLE 3. Surgical features of patients in synchronous and metachronous groups.

\begin{tabular}{lccccc}
\hline & \multicolumn{2}{c}{ Synchronous } & \multicolumn{2}{c}{ Metachronous } & P-value \\
\cline { 2 - 5 } & $\mathrm{n}$ & $\%$ & $\mathrm{n}$ & $\%$ & \\
\cline { 5 - 6 } Surgical treatment & & & & & \\
No & 20 & 52.6 & 11 & 68.8 & 0.274 \\
Yes & 18 & 47.4 & 5 & 31.2 &
\end{tabular}

Hepatic surgery

$\begin{array}{lcccc}\text { Nodulectomy } & 7 & 38.9 & 2 & 40.0 \\ \text { Segmentectomy } & 6 & 33.3 & 2 & 40.0 \\ \text { Right hepatectomy } & 1 & 5.6 & 1 & 20.0 \\ \text { Laparotomy } & 4 & 22.2 & 0 & 0.0\end{array}$

Colorectal neoplasms surgery

$\begin{array}{lllll}\text { Elective } & 21 & 61.8 & 9 & 60.0 \\ \text { Emergency } & 13 & 38.2 & 6 & 40.0\end{array}$

Intraoperative ultrasound

$\begin{array}{ccccc}\text { No } & 5 & 29.4 & 0 & 0.0 \\ \text { Yes } & 12 & 70.6 & 5 & 100.0\end{array}$

Blood transfusion

$\begin{array}{lcccc}\text { No } & 12 & 70.6 & 4 & 80.0 \\ \text { Yes } & 5 & 29.4 & 1 & 20.0 \\ \text { Surgical complications } & & & & \\ \text { No } & 14 & 77.8 & 3 & 60.0 \\ \text { Yes } & 4 & 22.2 & 2 & 40.0\end{array}$

Hepatic resection

$\begin{array}{ccccc}\text { R0 } & 11 & 78.6 & 4 & 80.0 \\ \text { R1 } & 2 & 14.3 & 1 & 20.0 \\ \text { R2 } & 1 & 7.1 & 0 & 0.0\end{array}$

Surgical margins

$\begin{array}{lllll}\geq 1 \mathrm{~cm} & 6 & 54.5 & 3 & 60.0 \\ <1 \mathrm{~cm} & 2 & 18.2 & 1 & 20.0 \\ \text { Positive } & 3 & 27.3 & 1 & 20.0\end{array}$

Recurrence

Yes

No

$\begin{array}{llll}9 & 81.8 & 3 & 75.0\end{array}$

Recurrence site

Liver

Lung

Liver and lung

Lung and brain

$\begin{array}{lll}81.8 & 3 & 75.0 \\ 18.2 & 1 & 25.0\end{array}$

0.770

Chi-squared test. 


\section{Recurrence-free survival}

The mean recurrence-free survival in the metachronous group was 9.75 months and $50 \%$ at 1 year, while in the synchronous group, the mean was 19.73 months and $63.3 \%$ at 1 year, as shown by the recurrence-free survival curves for the metachronous and synchronous groups (FIGURE 1).

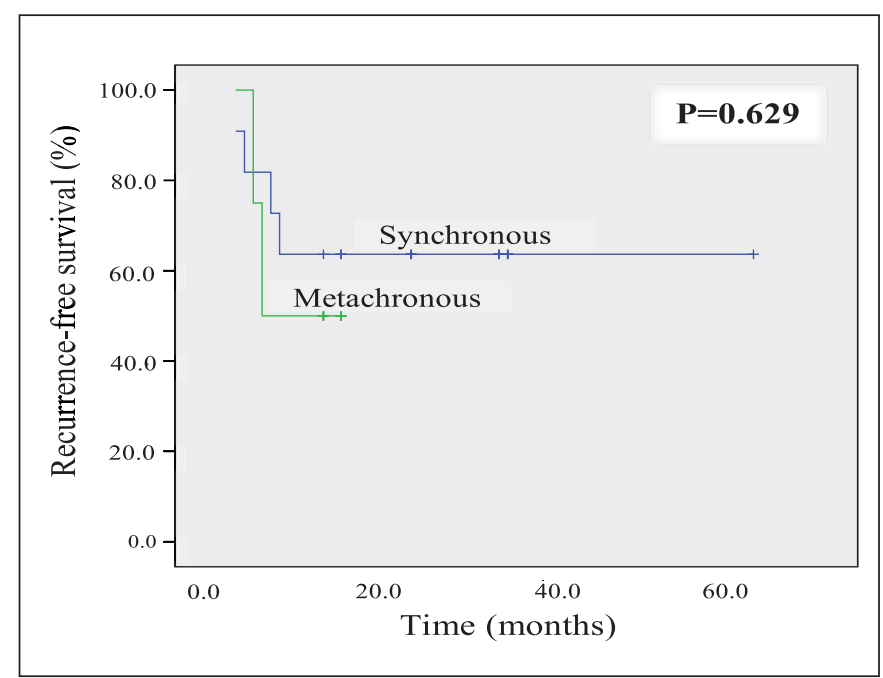

FIGURE 1. Recurrence-free survival curves in metachronous and synchronous groups.

Univariate analysis was performed using the Cox model of all patients undergoing potentially curative liver surgery. The variable surgical margins showed an association with recurrence-free survival in the univariate analysis, but it did not have statistical significance in the multivariate analysis.

\section{Overall survival}

The mean overall survival in the metachronous group was 20.00 months and $6.2 \%$ at 3 years, while in the synchronous group, the mean was 30.39 months and $31.6 \%$ at 3 years, as shown by the overall survival curve for the metachronous and synchronous groups (FIGURE 2).

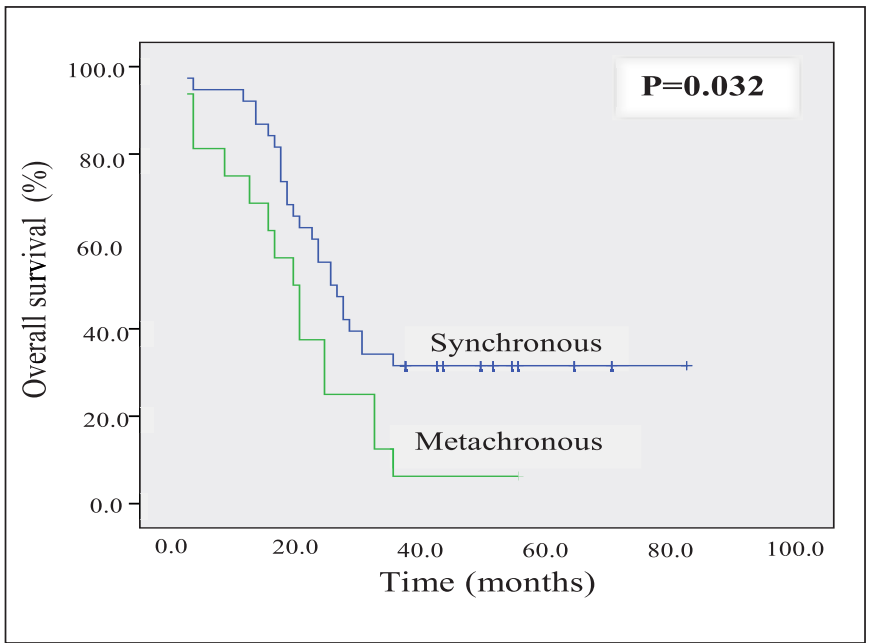

FIGURE 2. Overall survival curves in metachronous and synchronous groups.
A univariate analysis of the total study population was performed using the Cox model. For the multivariate analysis, we chose the variables age, metachronicity, extrahepatic disease, number of liver metastases, number of hepatic segments involved, distribution of liver metastases, use of biological drugs, and surgical treatment. The Cox multivariate analysis revealed metachronous hepatic metastasis as an independent variable related to worse overall survival $(P=0.036)$ and chemotherapy treatment combined with biological drugs as an independent variable related to better overall survival $(P=0.001)$. The multivariate analysis of overall survival is shown in TABLE 4.

TABLE 4. Multivariate analysis of prognostic factors of overall survival.

\begin{tabular}{lcccc}
\hline & $\begin{array}{c}\text { Hazard } \\
\text { Ratio }\end{array}$ & \multicolumn{2}{c}{$95 \%$ CI } & $P$-value \\
\hline Age $\leq 60$ years & 1.73 & 0.78 & 3.85 & 0.180 \\
Metachronicity & 2.66 & 1.06 & 6.63 & $0.036^{*}$ \\
Extrahepatic disease & 1.24 & 0.41 & 3.76 & 0.705 \\
Liver metastasis $>3$ & 3.12 & 0.69 & 14.04 & 0.138 \\
Hepatic segments involved $>4$ & 1.64 & 0.37 & 7.26 & 0.515 \\
Bilobar metastasis & 0.76 & 0.25 & 2.26 & 0.616 \\
Biological drugs & 0.21 & 0.08 & 0.50 & $0.001^{*}$ \\
Surgical treatment & 0.38 & 0.12 & 1.20 & 0.099 \\
\hline
\end{tabular}

Cox regression model. $* P<0.05$.

\section{DISCUSSION}

Metachronous colorectal liver metastasis is associated with better survival, especially in studies of prognostic scores ${ }^{(13-17)}$. However, its actual influence on prognosis is controversial ${ }^{(18-20)}$. The present study evaluated the survival of patients with colorectal liver metastasis in the metachronous and synchronous groups and the clinical, anatomical, and surgical characteristics of each group. Metachronous colorectal liver metastasis was associated with worse overall survival, an association that contravenes evidence of a worse prognosis for synchronous hepatic metas$\operatorname{tasis}^{(13-17,23)}$. Neo et al. conducted a database study and found a 3 -year overall survival of 33\% in metachronous metastases and $28 \%$ in synchronous metastases, with no significant difference ${ }^{(18)}$. Mekenkamp et al. also found no difference between the survival of patients with metachronous and synchronous metastasis ${ }^{(19)}$. Knopke et al. found worse survival in patients with synchronous colorectal liver metastasis, with a mean overall survival of 53 months for metachronous metastasis and 39 months for synchronous metastasis ${ }^{(16)}$. Kuo et al. also found an association between synchronous hepatic metastasis and worse prognosis, with lower overall survival (26.9\% vs $48.1 \%$ ) and recurrence-free survival $(13.8 \%$ vs. $38.9 \%)$ rates $^{(23)}$.

In the present study, some factors could explain the worse prognosis of metachronous metastasis. First is the oligosymptomatic nature of colorectal liver metastasis, which can sometimes delay the performance of follow-up examinations and consequently delay the diagnosis of metachronous metastasis ${ }^{(24)}$. This does not usually occur in patients with synchronous metastasis, since staging examinations are performed routinely at the time of diagnosis of the primary tumour. Another important factor is the influence of the neoplastic tumour microenvironment, in which the association of 
different molecular markers in metachronous and synchronous metastases is studied, which could be related to different carcinogenesis mechanisms, levels of tumour aggressiveness, and prognoses ${ }^{(25,26)}$.

In this study, another variable was also related to prognosis: the use of biological drugs was associated with better overall survival. This result may be related to the inversion of the predicted prognosis for metachronous metastasis. In our service, patients with synchronous colorectal liver metastases are treated with high-dose chemotherapy regimens based on the association of 5-fluoracil with oxaliplatin or irinotecan, and nearly half of these patients also received biological agents such as bevacizumab, cetuximab, and panitumumab. The same type of chemotherapeutic treatment was performed in patients who developed metachronous metastases, but $70 \%$ of these patients were exposed to these drugs before the appearance of liver metastasis, which theoretically could generate some degree of resistance to the chemotherapeutic and biological agents in the microbiological environment of the metastatic tumour ${ }^{(3,19)}$.

The metachronous and synchronous groups of this study were homogeneous in the characteristics analysed. Some studies have reported the association of unfavourable characteristics with synchronous hepatic metastases. For example, Tsai et al. found bilobular distribution, greater tumour number, and greater tumour diameter in synchronous metastases ${ }^{(21)}$, and Mekenkamp et al. found greater tumour invasion of the primary neoplasia in the synchronous group ${ }^{(19)}$. $\mathrm{Ng}$ et al. had a more heterogeneous group, with a higher prevalence of women and a higher mean age in the metachronous group, as well as fewer curative surgeries and more complications in the synchronous group ${ }^{(22)}$. The present study found no significant difference between the groups in any of the analysed variables. The homogeneity of the metachronous and synchronous groups in this sample strengthens our results because it reduces the biases related to the unfavourable clinical characteristics that could unbalance the groups statistically.

The study has some limitations, mainly related to the retrospective model of data collection from medical records and to the short period of follow-up.

The association of the synchronicity of liver metastasis with prognosis is not an exhausted topic of discussion and remains controversial, with divergent results. Therefore, there is a need for prospective studies with longer follow-up to evaluate the prognosis of metachronous and synchronous liver metastases in the context of modern multimodal therapeutic strategies.

\section{CONCLUSION}

Metachronous colorectal hepatic metastasis was associated with a worse prognosis for overall survival. There was no difference in recurrence-free survival between groups with metachronous and synchronous metastases.

\section{Authors' contributions}

Quireze Junior C: study design, interpretation of data, preparation of manuscript, critical revision of manuscript. Brasil AMS: Study literature review, data collect, preparation of manuscript. Morais LK: Study material contribution, literature review, critical revision of manuscript. Campion ER: study material contribution, interpretation of data, critical revision of manuscript. Taveira EJF: study material contribution, critical revision of manuscript. Rassi MC: study material contribution, critical revision of manuscript. All authors read and approved the final manuscript.

Quireze Junior C, Brasil AMS, Morais LK, Campion ER, Taveira EJF, Rassi MC. Metástase hepática colorretal metacrônica tem melhor prognóstico - é verdade? Arq Gastroenterol. 2018,55(3):258-63.

RESUMO - Contexto - As metástases hepáticas de câncer colorretal representam um importante problema de saúde pública devido à incidência crescente de câncer colorretal pelo mundo. A metástase hepática colorretal sincrônica está associada a pior sobrevida, no entanto, o pior prognóstico é assunto controverso. Objetivo - O objetivo do estudo foi avaliar a sobrevida livre de recorrência e a sobrevida global entre os grupos de pacientes com metástase hepática colorretal metacrônica e sincrônica. Método - Análise retrospectiva através de revisão de prontuários de pacientes com metástase hepática colorretal atendidos no período de 2013 a 2016, divididos em grupos metacrônico e sincrônico. Foram utilizados o modelo de regressão de Cox e o método de Kaplan-Meier com teste de Log-rank para comparação de sobrevida entre os grupos. Resultados - A média de sobrevida livre de recorrência no grupo metacrônico foi de 9,75 meses e 50\% em 1 ano, e no grupo sincrônico 19,73 meses e 63,3\% em 1 ano. A média de sobrevida global no grupo metacrônico foi de 20,00 meses e 6,2\% em 3 anos, e no grupo sincrônico 30,39 meses e 31,6\% em 3 anos. Os pacientes com metástase hepática metacrônica apresentaram pior sobrevida global em análise multivariada. O uso de drogas biológicas associadas ao tratamento quimioterápico foi relacionado ao melhor prognóstico em sobrevida global. Conclusão - A metástase hepática colorretal metacrônica foi associada a pior prognóstico na sobrevida global. Não houve diferença na sobrevida livre de recorrência entre as metástases metacrônica e sincrônica.

DESCRITORES - Neoplasias colorretais. Metástase neoplásica. Fígado. Prognóstico. Sobrevida. 


\section{REFERENCES}

1. Coimbra FJF, Ribeiro HSC, Marques MC, Herman P, Chojniak R, Kalil AN, et al. First Brazilian consensus on multimodal treatment of colorectal liver metastases. Module 1: Pre-treatment evaluation. Arq Bras Cir Dig. 2015;28:222-30.

2. Kemeny N. The management of resectable and unresectable liver metastases from colorectal cancer. Current opinion in oncology. 2010;22:364-73.

3. Ghiringhelli F, Hennequin A, Drouillard A, Lepage C, Faivre J, Bouvier AM. Epidemiology and prognosis of synchronous and metachronous colon cancer metastases: A French population-based study. Dig Liver Dis. 2014;46:854-58.

4. Ribeiro HSC, Torres OJM, Marques MC, Herman P, Kalil AN, Fernandes ESM, et al. I Brazilian consensus on multimodal treatment of colorectal liver metastases. Module 2: Approach to resectable metastases. Arq Bras Cir Dig. 2016;29:9-13.

5. Chan AK, Siriwardena AK. Improving definition of the term "synchronous liver metastases" from colorectal cancer. Hepatobiliary Pancreat Dis Int. 2016;15:458-60.

6. Torres OJM, Marques MC, Santos FN, Farias IC, Coutinho AK, Oliveira CVC, et al. Brazilian consensus for multimodal treatment of colorectal liver metastases. Module 3: Controversies and unresectable metastases. Arq Bras Cir Dig. 2016;29:173-79.

7. Abdel-Misih SRZ, Schmidt CR, Bloomston PM. Update and review of the multidisciplinary management of stage IV colorectal cancer with liver metastases. World J Surg Oncol. 2009;7:72.

8. Dattatreya S. Metastatic colorectal cancer-prolonging overall survival with targeted therapies. South Asian J Cancer. 2013;2:179-85.

9. Abdalla EK, Bauer TW, Chun YS, D'Angelica M, Kooby DA, Jarnagin WR. Locoregional surgical and interventional therapies for advanced colorectal cancer liver metastases: expert consensus statements. HPB (Oxford). 2013;15:119-30.

10. Maughan TS, Adams RA, Smith CG, Meade AM, Seymour MT, Wilson RH, et al Addition of cetuximab to oxaliplatin-based first-line combination chemotherapy for treatment of advanced colorectal cancer: results of the randomised phase 3 MRC COIN trial. Lancet. 2011;377:2103-14.

11. Hurwitz H, Fehrenbacher L, Novotny W, Cartwright T, Hainsworth J, Heim W, et al. Bevacizumab plus irinotecan, fluorouracil, and leucovorin for metastatic colorectal cancer. N Engl J Med. 2004;350:2335-42.

12. Douillard JY, Siena S, Cassidy J, Tabernero J, Burkes R, Barugel M, et al. Randomized, phase III trial of panitumumab with infusional fluorouracil, leucovorin, and oxaliplatin (FOLFOX4) versus FOLFOX4 alone as first-line treatment in patients with previously untreated metastatic colorectal cancer: the PRIME study. J Clin Oncol. 2010;28:4697-4705.

13. Fong Y, Fortner J, Sun RL, Brennan MF, Blumgart LH. Clinical score for predicting recurrence after hepatic resection for metastatic colorectal cancer: analysis of 1001 consecutive cases. Ann Surg. 1999;230:309-18.
14. Nordlinger B, Guiguet M, Vaillant JC, Balladur P, Boudjema K, Bachellier P, et al. Surgical resection of colorectal carcinoma metastases to the liver. A prognostic scoring system to improve case selection, based on 1568 patients. Association Francaise de Chirurgie. Cancer. 1996;77:1254-62.

15. Ueno H, Mochizuki H, Hatsuse K, Hase K, Yamamoto T. Indicators for treatment strategies of colorectal liver metastases. Ann Surg. 2000;231:59-66.

16. Konopke R, Kersting S, Distler M, Dietrich J, Gastmeier J, Heller A, et al. Prognostic factors and evaluation of a clinical score for predicting survival after resection of colorectal liver metastases. Liver Int. 2009;29:89-102.

17. Gomez D, Cameron IC. Prognostic scores for colorectal liver metastasis: clinically important or an academic exercise? HPB (Oxford). 2010;12:227-38.

18. Neo EL, Beeke C, Price T, Maddern G, Karapetis C, Luke C, et al. South Australian clinical registry for metastatic colorectal cancer. ANZ J Surg. 2011;81: 352-7.

19. Mekenkamp LJM, Koopman M, Teerenstra S, van Krieken JHJM, Mol L, Nagtegaal ID, et al. Clinicopathological features and outcome in advanced colorectal cancer patients with synchronous vs metachronous metastases. $\mathrm{Br} \mathrm{J}$ Cancer. 2010;103:159-64

20. Bockhorn M, Frilling A, Frühauf NR, Neuhaus J, Molmenti E, Trarbach T, et al. Survival of patients with synchronous and metachronous colorectal liver metastases--is there a difference? J Gastrointest Surg. 2008;12:1399-405.

21. Tsai MS, Su YH, Ho MC, Liang JT, Chen TP, Lai HS, et al. Clinicopathological features and prognosis in resectable synchronous and metachronous colorectal liver metastasis. Ann Surg Oncol. 2007;14:786-94.

22. Ng WWC, Cheung YS, Wong J, Lee KF, Lai PBS. A preliminary analysis of combined liver resection with new chemotherapy for synchronousand metachronous colorectal liver metastasis. Asian J Surg. 2009;32:189-97.

23. Kuo IM, Huang SF, Chiang JM, Yeh CY, Chan KM, Chen JS, et al. Clinical features and prognosis in hepatectomy for colorectal cancer with centrally locatedliver metastasis. World J Surg Oncol. 2015;13:92.

24. Van de Velde CJH, Boelens PG, Borras JM, Coebergh JW, Cervantes A, Blomqvist L, et al. EURECCA colorectal: multidisciplinary management: European consensus conference colon \& rectum. Eur J Cancer. 2014;50:1

25. Pantaleo MA, Astolfi A, Nannini M, Paterini P, Piazzi G, Ercolani G, et al. Gene expression profiling of liver metastases from colorectal cancer as potential basis for treatment choice. Br J Cancer. 2008;99:1729-34.

26. Perez-Villamil B, Romera-Lopez A, Hernandez-Prieto S, Lopez-Campos G, Calles A, Lopez-Asenjo JA, et al. Colon cancer molecular subtypes identified by expression profiling and associated to stroma, mucinous type and different clinical behavior. BMC Cancer. 2012;12:260. 